\title{
METAMUSEOLOGICAL CHALLENGES IN THE WORK OF ZBYNĚK STRÁNSKÝ

\section{PETER VAN MENSCH}

\section{ABSTRACT/ABSTRAKT:}

ICOFOM had always been a major platform for the recognition of Stránský as one of the key theoreticians from the Central European area. Outside ICOFOM his work has hardly been published in English, so in the English speaking museological (or, rather museum studies) world he thus remained largely unknown. Apart from the Czech and Slovak Republics, the most fertile soil for Stránský's ideas was and is Germany. Difference should be made between the former German Democratic Republic and the Bundesrepublik Deutschland. Among museologists of the German Democratic Republic, Stránský was well known and well respected. Before 1989, he was not very well received in the Bundesrepublik Deutschland. Mainly thanks to Friedrich Waidacher (Graz) and Christian MüllerStraten (Munich), Stránský's ideas became recently known to a wider German speaking audience.

In general, museologists all over the world were attracted to Stránský because he elaborated a consistent system of museology built around some discipline-specific concepts, such as musealisation and museality. Such a system was helpful in developing consistent study programmes. To Stránský developing a consistent system was crucial in his lifelong endeavour to prove that museology is a genuine academic discipline, but this concern was of little interest in "western" countries. Besides, in most of the new museology/museum studies programmes at European universities the museum as subject matter field is claimed by other disciplines: art history, history, ethnography, and increasingly: cultural studies. In these contexts, there is no felt need to adopt a rather rigid system and methodology like the one advocated by Stránský.

Stránskýs work on musealisation can still be of value in a further development of the concept. The challenge is to make a connection with the New Museology, Museum Studies and Critical Heritage Studies discourses. It would be worthwhile to make an in-depth comparison of the concepts of heritage as, for example, advocated by Laurajane Smith and Stránskýs concept of museality.

\section{Metamuzeologické výzvy v díle Zbyňka Stránského}

ICOFOM představovala již od svého vzniku největší platformu pro etablování Stránského jako jednoho z klíčových teoretiků v rámci středoevropského prostoru. Mimo rámec ICOFOM nebyly jeho práce prakticky vůbec publikovány $\mathrm{v}$ anglickém jazyce, $v$ důsledku čehož zůstal pro muzeology (či spíše muzejníky) v anglicky mluvících zemích takřka neznámý. Kromě České a Slovenské republiky našly Stránského myšlenky živnou půdu zejména v Německu. Je však potřeba rozlišovat mezi dřívější Německou demokratickou republikou a Německou spolkovou republikou. Muzeologové z východního Německa Stránského dobře znali a respektovali. V západním Německu však před rokem 1989 nenašel př́liš pozitivní ohlas. Hlavní zásluhu na tom, že se Stránského myšlenky dostaly $\mathrm{v}$ nedávné době do povědomí širšího publika v německy mluvících zemích nesou Friedrich Waidacher (Štýrský Hradec) a Christian Müller-Straten (Mnichov).

Z obecného hlediska si Stránský získal pozornost muzeologů po celém světě tím, že vypracoval pevný systém muzeologie spočívající na některých specifických oborových principech jako jsou muzealizace a muzealita. Tento systém byl velmi užitečný při vytváření odpovídajících studijních programů a zásadní význam měl také pro Stránského celoživotní snahu o definování muzeologie jako autonomní vědy. Tento aspekt však v „západních“ zemích nevzbudil př́liš velký zájem. Kromě toho, ve většině současných studijních programů se zaměřením na muzeologii/muzejnictví si muzeum jako předmět studia nárokují jiné obory: dějiny umění, historie, etnografie a stále častěji také kulturologie. Proto zde není důvod zavádět tak př́sný systém a metodologii jako vytvořil a obhajoval Stránský.

Stránského práce na téma muzealizace má i dnes svůj význam pro další rozvoj muzeologické teorie. Cílem je začlenění tohoto tématu do diskurzu v rámci nové muzeologie, muzejnictví a kritického studia kulturního dědictví. Stálo by za to porovnat do hloubky např. koncepci kulturního dědictví z pohledu Laurajane Smithové a Stránského koncept muzeality. 


\section{KEYWORDS/KLÍČOVÁ SLOVA:}

museology - museum studies - new museology - critical heritage studies - musealisation - museality muzeologie - muzejnictví - nová muzeologie - kritické studium kulturního dědictví - muzealizace - muzealita

Allow me to start with a personal anecdote. From 1977 to 1982 I was Head of the Department of Exhibitions and Education of the National Museum of Natural History at Leiden (Netherlands). As such I was invited to become member of the editorial board of the journal Museologia. The journal had a strong focus on the history, theory and practice of natural history museums. However, the publisher, Frans Heslinga, had the ambition to develop the journal into an (international) "magazine on theory and practice of museumwork". Contrary to the members of the editorial board, he was aware of the professional discourse in Central Europe. For example, the Polish museologist Jerzy Świecimski (Kraków) was a regular contributor on the theory of museum exhibition. In 1979 the journal received a text from a certain Zbyněk Stránský from Brno on "Museology as a science". Heslinga was enthusiastic, the members of the board were less convinced and actually shared some doubts about the validity of Stránský's ideas.

Anyway, the text was published. ${ }^{1}$ In 1982 I became lecturer of museology (defined as museum theory) at the Reinwardt Academie, a higher vocational training institute for museum staff, founded in Leiden in 1976. At once I remembered

1 STRÁNSKÝ, Z. Z. Museology as a science (A Thesis). Museologia, 1980, vol. 15, pp. 33-40. Together with his contribution to Museological Working Papers 1 (STRÁNSKÝ, Zbyněk Z. [Museology science or just practical museum work]. Museolo gical Working Papers, 1980 , no. 1, pp. 42-44.), it was his first publication on the subject in English in a 'western' context. DOLÁK, Jan and Jana VAVŘíKOVÁ. Muzeolog Z. Z. Stránský. Život a dílo. Brno: Masarykova univerzita, 2006.
Stránský's article and recognised its relevancy. My predecessor as lecturer of museology was the Academie's director, Giljam Dusée. He had studied at the École du Louvre (Paris) and became supporter of the ideas of George Henri Rivière. Soon it became clear to me that Stránský's approach, and the discourse in Central Europe in general, appealed to me much more than Rivière's approach. This feeling was strengthened when I started to become active in the ICOM International Committee for Museology (in 1982). ICOFOM became an important platform to meet colleagues - and to learn about their museological thinking - from the Soviet Union (Razgon), German Democratic Republic (Jahn, Schreiner), Yugoslavia (Maroević, Šola), Poland (Gluziński, Świecimski), and Czechoslovakia (Beneš, Jelínek, Stránský). Eventually, I would earn my PhD degree in Zagreb (in 1993) with Ivo Maroević as my 'Doktorvater'.

In my PhD thesis ${ }^{2}$ I reflected upon the early history of ICOFOM and analysed the contributions made by afore mentioned museologists to the work of this committee. Interestingly, when I presented my thesis at the University of Zagreb, Yugoslavia didn' t exist any longer with Zagreb now being the capital city of Croatia. The German Democratic Republic was abolished, as was the Soviet Union. Czechoslovakia was soon to be split into two sovereign states. Marxism-Leninism was no longer the leading ideology in Central Europe and with the demise of this ideology, Marxist-Leninist inspired museology lost much of its credibility. The death of Klaus Schreiner - who was proud to be "the last Stalinist museologist" - in 1991, was a symbolic end of a period. In the new geopolitical context, the role of Central European museology in ICOFOM diminished. ICOFOM

2 MENSCH, Peter van. Towards a methodology of museology. Zagreb: University of Zagreb, 1992. $\mathrm{PhD}$ thesis. had in fact been created on the basis of an opportunity collaboration of French and Central European museologists, but from the 1990s onwards, the role of Latin American museologists became increasingly important and the discourse changed accordingly. ICOFOM had always been a major platform for the recognition of Stránský as one of the key theoreticians from the Central European area. Through ICOFOM, Stránský is still honoured in Brazil where recently a conference was dedicated to his work. ${ }^{3}$ Outside ICOFOM his work has hardly been published in English. ${ }^{4}$ In the English speaking museological (or, rather museum studies) world "this chap from Brno" (Susan Pearce) thus remained largely unknown. ${ }^{5}$ The same can be said about the reception of his work in France even though he is frequently referred to in the Dictionnaire encyclopédique de muséologie $e^{6}$ and mentioned as one of the 18 most influential museologist of all time. ${ }^{7}$

3 Conference "Stránský: uma ponte Brno-Brasil", Rio de Janeiro 13-16 Oct. 2015. Chamada para textos e comunicações para o III Ciclo de Debates Internacional Stránský: uma ponte Brno-Brazil [online]. [cit. 2016-09-27]. Available from www: <http:// www.forumpermanente.org/noticias/2015/chamada-para-textos-e-comunicacoes-para-o-iii-ciclo-de-debates-internacional-stransky-uma-ponte-brno-brazil>

4 DOLÁK, Jan and Jana VAVŘÍKOVÁ. Muzeolog Z. Z. Stránský. Život a dílo. Brno: Masarykova univerzita, 2006. There are some English texts in Muzeologické sešity but the journal was not well known in the 'western' world. Several English texts were produced in the context of the International Sommer School of Museology but their distribution was limited.

5 Among the references to Stránský's work listed by Jan Dolák and Jana Vavř́ḱková no mention is made of English publications outside the ICOFOM sphere apart from obvious authors such as Tomislav Šola, Ivo Maroević, and myself. DOLÁK, Jan and Jana VAVRÍKOVÁ. Muzeolog Z. Z. Stránský. Život a dílo. Brno: Masarykova univerzita, 2006, pp. 40-45

6 DESVALLÉES, André and François MAIRESSE. Dictionnaire encyclopédique de muséologie. Paris: Armand Collin, 2011.

7 Idem. Desvallées worked with Stránský in ICOFOM; Mairesse participated in the International Summer School of Museology. Although they respect his work, they keep some distance from his ideas (see MENSCH, Peter van. Museality at breakfast. The concept of museality in contemporary museological discourse. Museologica Brunensia, 2015, vol. 4, no. 2, pp. 14-19.). 


\section{Stránský and Germany}

Apart from the Czech and Slovak Republics, the most fertile soil for Stránský's ideas was and is Germany. ${ }^{8}$ Difference should be made between the former German Democratic Republic and the Bundesrepublik Deutschland. Among museologists of the German Democratic Republic, Stránský was well known and well respected. In 1982 the Institut für Museumswesen published in its Schriftenreihe a volume on Museologische Forschung in der ČSSR. ${ }^{9}$ Among the 13 texts from the period 1968-1982 two were written by Stránský. In his introduction editor Rolf Lang emphasised the key role of Stránský in the development of Czechoslovakian museology. The year before, Stránský has also started to contribute to Neue $\mathrm{Mu}$ seumskunde. ${ }^{10}$ In the same period of time Klaus Schreiner started to publish serious criticism. ${ }^{11}$ This Stránský-Schreiner controversy has been analysed by Andreas Hanslok. ${ }^{12}$ Focussing on Stránský's concept of museality, Schreiner accused him of having adopted non-marxist bourgeois idealist points of view. Schreiner's ideas were not widely shared among museologists of the GDR, or at least they did not agree

8 Because of limited knowledge of the languages, I am not aware of the reception of Stránský's ideas in other countries of Central Europe.

9 LANG, Rolf (ed.). Museologie in der Tschechoslowakischen Sozialistischen Republik. Berlin, 1982.

10 In 1964 Stránský had already participated in a discussion on the specificity of museology. About this discussion, see SCHEUNEMANN, Jan. „Gegenwartsbezogenheit und Parteinahme für den Sozialismus". Geschichtspolitik und regionale Museumsarbeit in der SBZ/DDR 1945-1971.

Berlin: Metropol Verlag, 2009, pp. 331-340.

Scheunemann does not refer to Stránský's role.

11 For example in his $\mathrm{PhD}$ thesis (SCHREINER, Klaus. Einführung in die Museologie - ein Beitrag zu den theoretischen Grundlagen der Museumsarbeit. Neubrandenburg, 1982.), in Leipzig often referred to as "das grüne Ungeheuer".

12 HANSLOK, Andreas. Museologie und Archivwis senschaft in der DDR. Abgrenzung und Annäherung zweier Nachbarwissenschaften. Marburg: Tectum Verlag, 2008, Chapter 14. Also in MÜLLER-STRATEN, Christian. Wie in der DDR Museologie gemacht wurde: Die kommunistische Abrechnung mit Z. Z. Stránský. Museum aktuell, 2005, Juli August, pp. 40-41. with the harsh tone of Schreiner's criticism. In fact, his reputation was hardly harmed. The Fachschule für Museologen ${ }^{13}$ at Leipzig remained a strong institutional basis for this thinking. Also after 1989 the Fachschule supported Stránskýs ideas, at least as long as Katharina Flügel was director. ${ }^{14}$ Flügel's Einführung in die Museologie (first edition 2005) became a relatively widely used handbook at German museology courses.

Before 1989, Stránský was not very well received in the Bundesrepublik Deutschland. Wolfgang Klausewitz, board member of ICOFOM, made some efforts to introduce Stránskýs thinking. He was one of the very few West-German museologist to create bridges between museology in the Bundesrepublik and the museologies that were advocated in the GDR and Czechoslovakia. ${ }^{15}$ In 1988 Stránský was invited to speak at a joint conference of ICOM-Germany, ICOM-Austria and ICOM-Switzerland. ${ }^{16}$ Considering the dis-

13 Since 1992 Studiengang Museologie at the Hochschule für Technik, Wirtschaft und Kultur Leipzig.

14 FLÜGEL, Katharina. Einführung in die Museologie. Darmstadt: Wissenschaftliche Buchgesellschaft, 2005; FLÜGEL, Katharina and Arnold VOGT (eds.). Museologie als Wissenschaft und Beruf in der modernen Welt. Leipziger Gespräche zur Museologie. Leipzig: Hochschule für Technik, Wirtschaft und Kultur, 1995. This Leipzig tradition is also reflected in the contents of the journal Curiositas. Jahrbuch für Museologie und museale Quellenkunde (since 2001). Editors are Katharina Flügel and Volker Schimpff (former lecturer at the Fachschule für Museologen). In 2015 the responsibility for the journal was handed over to the museology department of the University of Graz, Austria. BEIER, Hans-Jürgen and Volker SCHIMPFF. Editorial. Curiositas.

Jahrbuch für Museologie und museale Quellenkunde, 2014-2015, no. 14-15, p. 2.

15 KLAUSEWITZ, Wolfgang. Zur Geschichte der Museologie (1878-1988). In AUER, Hermann (ed.) Museologie. Neue Wege - Neue Ziele. Bericht über ein internationales Symposium, veranstaltet von den ICOM-Nationalkomitees der Bundesrepublik Deutschland, Österreichs und der Schweiz vom 11. bis 14. Mai 1988 am Bodensee. München: K. G. Sauer, 1989, pp. 20-37.

16 STRÁNSKÝ, Zbyněk. Die theoretischen Grundlagen der Museologie als Wissenschaft. In AUER, Hermann (ed.). Museologie. Neue Wege - Neue Ziele. Bericht über ein internationales Symposium, veranstaltet von den ICOM-Nationalkomitees der Bundesrepublik Deutschland, Österreichs und der Schweiz von 11. bis 14. Mai 1988 am Bodensee. München: K. G. Sauer, 1989, pp. 38-47. cussion, his presentation and the others on museology and ICOFOM, did not attract much interest among the participants. ${ }^{17} \mathrm{~A}$ few years later it was Friedrich Waidacher's Handbuch der Allgemeinen Museologie $^{18}$ that played a key role in introducing Stránskýs thinking to a wider German speaking audience. Thanks to the legacy of Waidacher, the ideas of Stránský are adopted as key subject of interest at the University of Graz in Austria. ${ }^{19}$ In Graz, Waidacher is considered an "in alle Richtungen strahlenden museologischen Komet, ${ }^{\text {" } 20}$ who developed the theory of museology on the basis of Stránský's work. Museality was

17 AUER, Hermann (ed.). Museologie. Neue Wege Neue Ziele. Bericht über ein internationales Symposium, veranstaltet von den ICOM-Nationalkomitees der Bundesrepublik Deutschland, Österreichs und der Schweiz vom 11. bis 14. Mai 1988 am Bodensee. München: K. G. Sauer, 1989, pp. 97-98. A similar conference on the characteristics of museology, organised in 1971 did not refer to discussions in Central and East Europe at all. DYROFF, HansDieter (ed.). Museologie. Bericht über ein internationales Symposium, veranstaltet vom Deutschen Nationalkomitee des Internationalen Museumsrates (ICOM) in Zusammenarbeit mit der Deutschen UNESCO-Kommission vom 8. bis 13. März 1971 in München. Köln: Deutsche UNESCO-Kommission, 1973.

18 WAIDACHER, Friedrich. Handbuch der Allgemeinen Museologie. Wien: Böhlau Verlag, 1993.

19 BIEDERMANN, Bernadette, Marlies RAFFLER and Nikolaus REISINGER. Geleitwort. Curiositas. Jahrbuch für Museologie und museale Quellenkunde, 2012-2013, no. 12-13, pp. 1-2; BIEDERMANN, Bernadette. Theoretische Modelle und aktuelles museales Ausstellungswesen im Spiegel des Theorems der Musealität. Museologica Brunensia, 2015, vol. 4, no. 2, pp. 33-41; RAFFLER, Marlies. Spiegel der Nation? Zugänge zur Historischen Museologie am Beispiel der Genese von Landes- und Nationalmuseen in der Habsburgermonarchie. Wien: Böhlau Verlag, 2007, p. 48. In 2002 Waidacher was appointed as honorary professor of "Allgemeine Museologie" at the Karl-Franzens Universität, Graz. BIEDERMANN, Bernadette and Marlies RAFFLER. Dem Museologen, Volkskundler, Jazzmusiker, Komponisten, Arrangeur, Pädagogen, Museumskonsulenten, Mentor, Philosophen, Polyhistor, Menschen und Freund Friedrich Waidacher zum 80. Geburtstag. Curiositas. Jahrbuch für Museologie und museale Quellenkunde, 2014-2015, no. 14-15, pp. 3-14. He was succeeded by Marlies Raffler as professor of "Historische Museologie".

20 BIEDERMANN, Bernadette and Marlies RAFFLER. Dem Museologen, Volkskundler, Jazzmusiker, Komponisten, Arrangeur, Pädagogen, Museumskonsulenten, Mentor, Philosophen, Polyhistor, Menschen und Freund Friedrich Waidacher zum 80. Geburtstag. Curiositas. Jahrbuch für Museologie und museale Quellenkunde, 2014-2015, no. $14-15$, p. 3. 
re-branded as "das Stránský-Waidacher Theorem der Musealität". ${ }^{21}$

Stránský's ideas are strongly supported by Christian Müller-Straten, publisher of, among others, the museums journal Museum aktuell. ${ }^{22}$ Museum aktuell became Stránský's most important international platform in the beginning of the $21^{\text {st }}$ century. ${ }^{23} \mathrm{He}$ used this platform to justify himself and to criticise others. The most explicit justification of his position was published in $2001 .{ }^{24} \mathrm{He}$ described how the communist regime opposed his work. ${ }^{25}$ In particular he commented on the controversy with Klaus Schreiner concerning the concept of

21 BEIER, Hans-Jürgen and Volker SCHIMPFF. Editorial. Curiositas. Jahrbuch für Museologie und museale Quellenkunde, 2014-2015, no. 14-15, p. 1. This would make Christian Müller-Straten very angry. To him, Waidacher "remains a mere transporter of Stránský's original thoughts. But as Waidacher does a lot to disseminate Stránský's thinking, the only thing we all have to do is to get Waidacher back to earth and to speak absolutely clear on Stránský and his achievements to Museology". MÜLLER-STRATEN, Christian. The contribution of Zbyněk Stránský to Museology and the contribution of the Brno Museology School. In Muzealizace $v$ soudobé společnosti a poslání muzeologie/Musealization in contemporary society and role of museology. Anthology from symposium with foreign participation on the occasion of anniversary of the founder of the Brno museology school Zbyněk Z. Stránský. Technical Museum in Brno, $8^{\text {th }}-10^{\text {th }}$

November 2006. Prague: Asociace muzeí a galerií

České republiky, 2008, p. 30.

22 MÜLLER-STRATEN, Christian. The contribution of Zbyněk Stránský to Museology and the contribution of the Brno Museology School. In

Muzealizace $v$ soudobé společnosti a poslání muzeologie/Musealization in contemporary society and role of museology. Anthology from symposium with foreign participation on the occasion of anniversary of the founder of the Brno museology school Zbyněk Z. Stránský. Technical Museum in Brno, $8^{\text {th }}-10^{\text {th }}$ November 2006. Prague: Asociace muzeí a galeriî České republiky, 2008, pp. 27-35.

23 It is fair to say that Müller-Straten also published critical reviews of Stránský's ideas (for example MAROEVIĆ, Ivo. Zur Kritik der museologischen Theorien Zbynek Z. Stránskýs. Museum aktuell, 2001, Juli, pp. 2887-2892.).

24 STRÁNSKÝ, Zbyněk Z. Ist Museologie eine kommunistische Wissenschaft? Eine Entgegnung auf deutsche Einstellungen. Museum aktuell, April 2001, pp. 2758-2761.

25 On Stránský's struggles with the regime, see also KIRSCH, Otakar. Vysokoškolská výuka muzeologie v Brně v době normalizace a nástupu demokratického režimu. Museologica Brunensia, 2014 , vol. 3 , no. 5 , pp. $12-20$. museality. ${ }^{26}$ In his text he referred to many authors that have adopted his ideas (such as Waidacher), but his opinion about his sympathizers is ambivalent. For example, in 2006 he criticised the handbooks published by two of his most ardent supporters pointing out that "the methodological shortcomings and the confusion evident in both publications reflect the state of current professional museology". ${ }^{27}$ The German text is even more impolite than the English summary: "Beide Titel [...] signalisieren leider einen erheblichen Mangel an professioneller museologische Durchdringung". "Erhebliche Mangel“, serious defects, a not very helpful qualification to create coalitions.

The increased focus on New Museology at museology and museum studies programmes in Germany, tends to marginalize the type of thinking of which Stránský was a representative, while at the same time doubts persisted as to the validity of museology as academic discipline, ${ }^{28}$ or even the existence of a whole tradition of thinking about museums. In November 2016 a conference was organised by the Westfälische Wilhelms-Universität (Münster) in the Bode-Museum at Berlin. In the brochure it is suggested that the aim of this conference is to establish a "Philosophy of Museums", suggesting that fundamental

$\overline{26 \text { See also HANSLOK, Andreas. Museologie }}$ und Archivwissenschaft in der DDR. Abgrenzung und Annäherung zweier Nachbarwissenschaften. Marburg: Tectum Verlag, 2008 and KIRSCH, Otakar. Vysokoškolská výuka muzeologie v Brně v době normalizace a nástupu demokratického režimu. Museologica Brunensia, 2014, vol. 3, no. 5, pp. 12-20.

27 STRÁNSKÝ, Zbyněk Z. Noch eine „knapp gefasste Museologie“. Museum aktuell, November 2008, p. 7.

28 HEESEN, Anke te. Theorien des Museums zur Einführung. Hamburg: Junius Verlag, 2012. questions have not yet been dealt with by existing museum theories. ${ }^{29}$

\section{Three questions to answer}

In the following I would like to find an answer to three questions: (1) what attracted people to Stránský's ideas, (2) why did these ideas not attract wider attention, and (3) what elements from Stránský's heritage could we use for future development. It is not my intention to analyse Stránský's ideas as such, neither will I explore their origin and development. Just one remark: little attention has been given to developments in Stránský's thinking. For example, his definition of museality has changed over the years. ${ }^{30}$ In his Introduction to museology and other publications, Ivo Maroević has adopted the concept of museality, but refers to a definition of $1970 .{ }^{31}$ As a consequence there is some tension between Maroević's concept of museality and Stránský's later approach.

\section{What attracted people to Stránský's ideas?}

Contrary to Western Europe, there was a strong urge among Central and Eastern European museologists to prove that their specialist

29 "Die geplante Tagung ist der Bestandsaufnahme und der Grundlegung einer Philosophie des Museums gewidmet, deren Gegenstand [...] museumsphilosophische Fragen sind, die die etablierte Museum stheorie, aber auch die 'New Museology' allenfalls am Rande streifen". In her own publications, the organiser Prof. Bernadette Collenberg-Plotnikov, specialist on the aesthetics of the Hegelian School, does not appear to be familiar with the key corpus of museological literature. COLLENBERG-PLOTNIKOV, Bernadette. Die Musealisierung des

Alltäglichen. Zur Bedeutung der Institutionen für die Kunst. In WIESING, Lambert (ed.). Ästhetik und Alltagserfahrung. VII. Kongress der Deutschen Gesellschaft für Ästhetik. [Jena], 2008; COLLENBERG-PLOTNIKOV, Bernadette. Kunst zeigen Kunst machen. Überlegungen zur Bedeutung des Museums. In COLLENBERG-PLOTNIKOV, Bernadette (ed.). Musealisierung und Reflexion. Gedächtnis - Erinnerung - Geschichte. München: Wilhelm Fink Verlag, 2011.

30 MENSCH, Peter van. Towards a methodology of museology. Zagreb: University of Zagreb, 1992 , pp. 45 and 151. PhD thesis.

31 MAROEVIĆ, Ivo. Introduction to Museology the European Approach. München: Verlag Dr. Christian Müller-Straten, 1998, pp. 130-132. 
field should be accepted as genuine academic discipline. This may not have been Jelínek's intention when he initiated a museum studies department at the Jan Evangelista Purkynĕ University (Brno) in 1963. It became however a lifelong endeavour of Stránský as the department's most important staff member. ${ }^{32}$ On 22-24 March 1965, Stránský organised a conference in which the characteristics of museology as disciplines were discussed. ${ }^{33}$ During the 1960s, this conference was followed by two other international conferences. ${ }^{34}$ The conferences positioned Stránský as important thinker in the field and constituted the concept of the museological "School of Brno".

As his international network gradually expanded, Stránský gained increased respect, also in the Soviet Union. ${ }^{35}$ Leading Soviet museologist Awraam Razgon credited him as the person who has developed the theoretical foundation of museology as academic discipline at

32 About the early history of the department, see RUTAR, Václav. Vznik, vývoj a práce externí katedry muzeologie v Brnĕ v letech 1963-1969. Museologica Brunensia, 2014, vol. 3, no. 5, pp. 4-11 and KIRSCH, Otakar. Vysokoškolská výuka muzeologie v Brně v době normalizace a nástupu demokratického režimu. Museologica Brunensia, 2014, vol. 3, no. 5, pp. 12-20.

33 STRÁNSKÝ, Z. Z. (ed.). Sborník materiálů prvého muzeologického sympozia. Brno: Moravské muzeum, 1966.

34 RUTAR, Václav. Vznik, vývoj a práce externî katedry muzeologie v Brně v letech 1963-1969.

Museologica Brunensia, 2014, vol. 3, no. 5, p. 8.

The conference that was held on 20-21 October 1967 resulted in the creation of the ICOM International Committee for the Training of Personnel. KIRSCH, Otakar. Vysokoškolská výuka muzeologie v Brně v době normalizace a nástupu demokratického režimu. Museologica Brunensia,

2014, vol. 3, no. 5, p. 14

35 GUBARENKO, Maria. Czech-Russian (Czechoslovak-Soviet) cooperation in the field of formation and development of museology as a science. Museologica Brunensia, 2016, vol. 5, no. 1, pp. 15-25. its fullest. ${ }^{36}$ This is also the opinion Christian Müller-Straten has expressed at different occasions. ${ }^{37}$ Müller-Straten even suggested that "the main teaching museologists in Zagreb, Jyväskylä, Graz, Amsterdam as well as in Switzerland are based on the basic thoughts of Prof. Stránský. And as his thoughts are in a positive sense timeless and including all cultures of the world, his system of Museology can also be used in Africa, even if this was doubted some years ago by Tomislav Sola." 38 I do think Tomislav Šola was right, and I also think Müller-Straten overestimated the impact of Stránský's ideas in the four (five) teaching centres. These ideas did certainly influence teaching at those centres, but despite the alleged timelessness, this influence did not last into the present. However, it is not by coincidence that Müller-Straten mentioned four training centres. He could easily have mentioned more. What my colleagues and myself attracted

36 In HERBST, Wolfgang and Konstantin G. LEVYKIN (eds.). Museologie. Theoretische Grundlagen und Methodik der Arbeit in Geschichtsmuseen. Berlin: VEB Deutscher Verlag der Wissenschaften, 1988 , p. 21 . This publication was a joint project of GDR and USSR museologists. The chapter on "Museologie als wissenschaftliche Disziplin" was written by Razgon. Stránský described how he needed to meet Razgon in city parks in order not to be bugged. According to Stránský it was difficult for Razgon to be positive about his ideas, which seems to be in contradiction with the way Razgon wrote about Stránský in HERBST, Wolfgang and Konstantin G. LEVYKIN (eds.). $M u$ seologie. Theoretische Grundlagen und Methodik der Arbeit in Geschichtsmuseen. Berlin: VEB Deutscher Verlag der Wissenschaften, 1988.

37 MÜLLER-STRATEN, Christian. The contribution of Zbyněk Stránský to Museology and the contribution of the Brno Museology School. In Muzealizace $v$ soudobé společnosti a poslání muzeologie/Musealization in contemporary society and role of museology. Anthology from symposium with foreign participation on the occasion of anniversary of the founder of the Brno museology school Zbyněk Z. Stránský. Technical Museum in Brno, $8^{\text {th }}-10^{\text {th }}$ November 2006. Prague: Asociace muzeí a galerií České republiky, 2008, pp. 27-35.

38 MÜLLER-STRATEN, Christian. The contribution of Zbyněk Stránský to Museology and the contribution of the Brno Museology School. In Muzealizace $v$ soudobé společnosti a poslání muze ologie/Musealization in contemporary society and role of museology. Anthology from symposium with foreign participation on the occasion of anniversary of the founder of the Brno museology school Zbyněk Z. Stránský. Technical Museum in Brno, $8^{\text {th }}-10^{\text {th }}$ November 2006. Prague: Asociace muzeí a galerií České republiky, 2008, p. 27. to Stránský was that he "invented a system”, to use Müller-Straten's words. ${ }^{39}$ Such a system was helpful in developing a consistent study programme as became clear to us in the Netherlands in the early 1980s.

The most elaborate introduction of Stránský's system outside Czechoslovakia/Czech \& Slovak Republics, is Waidacher's Handbuch (1993). ${ }^{40}$ As most of the ICOFOM members were not aware of Waidacher's publication(s), ${ }^{41}$ they mostly depended on two English texts presented by Anna Gregorová (Bratislava), ${ }^{42}$ which they apparently seemed to find more comprehensive and more accessible than Stránský's own ICOFOM texts. Anyway, what appealed to many "teaching museologists" as referred to above, was the concept of a specific human relation

39 MÜLLER-STRATEN, Christian. The contribution of Zbyněk Stránský to Museology and the contribution of the Brno Museology School. In Muzealizace $v$ soudobé společnosti a poslání muzeologie/Musealization in contemporary society and role of museology. Anthology from symposium with foreign participation on the occasion of anniversary of the founder of the Brno museology school Zbyněk Z. Stránský. Technical Museum in Brno, $8^{\text {th }}-10^{\text {th }}$ November 2006. Prague: Asociace muzeí a galerií České republiky, 2008, p. 31

40 Müller-Straten refers to Waidacher as "mere transporter of Stránský's original thoughts" having received more credits than justified. MÜLLERSTRATEN, Christian. The contribution of Zbyněk Stránský to Museology and the contribution of the Brno Museology School. In Muzealizace v soudobé společnosti a poslání muzeologie/Musealization in contemporary society and role of museology. Anthology from symposium with foreign participation on the occasion of anniversary of the founder of the Brno museology school Zbyněk Z. Stránský. Technical Museum in Brno, $8^{\text {th }}-10^{\text {th }}$ November 2006. Prague: Asociace muzeí a galerií České republiky, 2008, p. 30 and 34. In the German Wikipedia page on "Museologie", Müller-Straten (?) added that Waidacher's Handbuch was published before Stránský's concept of museology was fully developed. Museologie. In Wikipedia. Die freie Enzyklopädie [online]. [cit. 2016-09-27]. Available from www: < https://de.wikipedia.org/wiki/Museologie >

41 Waidacher did not contribute to ICOFOM's publication series.

42 In Museological Working Papers 1 (1980) and 2 (1981). She also contributed to ICOFOM Study Series 10 (1986) and 12 (1987). In a private conversation, Stránský admitted that he found it difficult to accept that Gregorová was credited for ideas that she derived from him. See also STRÁNSKÝ, Zbyněk Z. Ist Museologie eine kommunistische Wissenschaft? Eine Entgegnung auf deutsche Einstellungen. Museum aktuell, April 2001, p. 2760. 
towards reality as object of interest in museology. Paradoxically, this might also be the very reason why at many places "teaching museologists" later lost interest in Stránský's ideas.

\section{Why did Stránskýs ideas not attract wider attention?}

When we focus on the non-German speaking world, the first problem seems to be a language problem connected with differences in epistemological thinking. ${ }^{43}$ Only a few texts of Stránský were published in English and they circulated mainly within a limited ICOFOM context. ${ }^{44}$ It is obvious that the present international museological professional discourse is mainly dominated by authors from Great Britain, United States and Australia. This is, for example, clearly shown in the four volume International Handbooks of Museum Studies, published in $2015 .^{45}$ In the introduction to the first volume (Museum Theory), the editors, Kylie Message and Andrea Witcomb, give 54 publications in their bibliography, all in English. Bourdieu, Deleuze, Foucault and Habermas are mentioned (not surprising in this context), but they are the only continental-European authors referred to. ${ }^{46}$ This is symptomatic of the Handbooks as a whole: the professional output from continental-Europe, Latin-America, Africa and Asia is almost completely ig-

43 MAIRESSE, François. Museology at a cross roads. Museologica Brunensia, 2015, vol. 4, no. 2, p. 5.

44 Some ICOFOM texts were also published in French. Texts produced in connection with the International Summer School of Museology were also translated into French but were not distribu ted outside the ISSOM context.

45 MACDONALD, Sharon and Helen Rees LEAHY (eds.). International Handbooks of Museum Studies. Chichester: Wiley-Blackwell, 2015.

46 MESSAGE, Kylie and Andrea WITCOMB Introduction: museum theory. An expanded field. In WITCOMB, Andrea and Kylie MESSAGE (eds.) Museum Theory. The International Handbooks of Museum Studies 1. Chichester: Wiley-Blackwell, 2015, pp. xxxv-1xiii. nored. ${ }^{47}$ Part of it is the implicit distinction between museum theory, museum studies and museology. When Message and Witcomb speak of "the first phase of museum studies" in the $1990 \mathrm{~s}^{48}$ they ignore the work of the ICOM International Committee for Museology and the discussions on museology that preceded its establishment (in 1977). ${ }^{49}$

One of the key concerns of Stránský, to prove that museology was a genuine academic discipline, was of little interest in "western" countries. Besides, new approaches towards the understanding of the development of scientific fields emerged..$^{50}$ As far as I know, the University of Graz is the only place outside the Czech and Slovak Republics where they still follow the Stránský/Waidacher system of museology ${ }^{51}$ In most of the new museology/museum studies programmes at European universities the subject matter field is claimed by other disciplines: art history, history, ethnography, and increasingly: cultural

47 MENSCH, Peter van. Needles in a haystack Some reflections from the Working Group on Resources. COMCOL Newsletter, 2015, vol. 29, pp. 19-21.

48 MESSAGE, Kylie and Andrea WITCOMB. Introduction: museum theory. An expanded field. In WITCOMB, Andrea and Kylie MESSAGE (eds.). Museum Theory. The International Handbooks of Museum Studies 1. Chichester: Wiley-Blackwell, 2015, p. xxxvii.

49 In a similar way, Janet Marstine writes about "new museum theory" without any reference to museological work before the publication of Peter Vergo's New Museology (1989), or discussions that took place, and still take place, outside the British-American-Australian part of the world. MARSTINE, Janet. Introduction. In MARSTINE, Janet (ed.). New museum theory and practice. Oxford: Blackwell, 2008, pp. 1-36.

50 MAIRESSE, François. Museology at a crossroads. Museologica Brunensia, 2015, vol. 4, no. 2, p. 6.

51 The university is decribed as "das letzte Refugi um und künftig hoffentlich eine erneute Pflanzstätte der wissenschaftlichen Museologie im deutschen Sprachraum“. BEIER, Hans-Jürgen and Volker SCHIMPFF. Editorial. Curiositas. Jahrbuch für Museologie und museale Quellenkunde, 2014-2015, no. $14-15$, p. 2. studies. ${ }^{52}$ In these contexts there is no felt need to adopt a rather rigid system and methodology like the one advocated by Stránský and Waidacher.

As mentioned above, many "teaching museologists" were attracted by the concept of a specific human relation towards reality as object of interest in museology, rather than the more tradition approach focussing on the museum institution. It seems that the field of Museum Studies as it emerged from the New Museology, has given a new dimension to the traditional museum focussed museology, whereas the related field of Critical Heritage Studies (also rooted in the British New Museology) has absorbed any approach focussing on specific relations toward reality as expressed in the concept of heritage. ${ }^{53}$

As is show, for example, in Markus Walz's Handbuch Museum, ${ }^{54}$ the "Anglosaxon" Museum Studies and Critical Heritage Studies approaches have hardly found their way into the German museology discourse. ${ }^{55}$ Nevertheless, the broad adoption

52 WALZ, Markus. On the current ascendancy of special museology in Germany. Museologica Brunensia, 2015, vol. 4, no. 2, pp. 20-27; LUDWIG, Andreas and Markus WALZ. Museen als Forschungsgegenstand anderer Wissenschaften. In WALZ, Markus. Handbuch Museum. GeschichteAufgaben - Perspektiven. Stuttgart: J. B. Metzler, 2016, pp. 375-381. Markus Walz, however, does not mention cultural studies as one of the major academic fields claiming museums as a major subject matter. The explanation might be his focus on Germany.

53 MENSCH, Peter van. Museologie - Wissenschaft für Museen. In WALZ, Markus. Handbuch Museum. Geschichte - Aufgaben-Perspektiven. Stuttgart: J. B. Metzler, 2016, pp. 373-374.

54 WALZ, Markus. Handbuch Museum. Geschich te-Aufgaben - Perspektiven. Stuttgart: J. B. Metzler, 2016.

55 The recent (2015) appointment of Sharon Macdonald, one of the exponents of the New Museology, as professor at the Institut für Europäische Ethnologie (Humboldt Universität, Berlin) is an interesting development. At the one hand it gives New Museology a solid basis in Germany, at the other hand it is interesting that in the context of the Institute for European Ethnology she became director of the Centre for Anthropological Research on Museums and Heritage, thus illustrating the growing interest of other disciplines in the subject matter field that is traditionally claimed by museology. 
of the concept of musealisation in Germany is an expression of a similar emerging interest as shown by the popularity of Critical Heritage Studies elsewhere. This has, however, very little to do with Stránský's work. German authors usually refer to a lecture of Hermann Lübbe from $1981 .^{56}$ The first word of this lecture is "Musealisierung" and throughout the text many times the words museology and museum philosophy are used. There are many references to contemporary publications in English and German, but not a single reference to museological texts published in the German Democratic Republic or Czechoslovakia. Neither does Lübbe refer to Jean Baudrillard and Henri Pierre Jeudy. As Eva Sturm has shown, these two French authors used "muséification" already in the 1970s. ${ }^{57}$ Writing about musealisation, Eva Sturm and François Mairesse ${ }^{58}$ discuss Stránský's ideas but by doing so, they tend to overestimate his contribution to the international discourse. ${ }^{59}$ It is interesting that in developing ideas regarding establishing a museum philosophy, Bernadette Collenberg-Plotnikov goes back to the musealisation theory of Hermann Lübbe, who is invited speaker at the November 2016 conference mentioned above.

What elements from Stránskýs heritage could we use for future development?

56 For example: LÜBBE, Hermann. Der Fortschritt und das Museum. Über den Grund unseres Vergnügens an historischen Gegenständen. The 1981 Bithell Memorial Lecture. London: Institute of Germanic Studies, 1982

57 STURM, Eva. Konservierte Welt. Museum und Musealisierung. Berlin: Dietrich Reimer Verlag, 1991.

58 MAIRESSE, François. Muséalisation. In DESVALLÉES, André and François MAIRESSE. Dictionnaire encyclopédique de muséologie. Paris: Armand Collin, 2011, pp. 251-269.

59 Sturm refers to Stránský's lecture on museality at the Reinwardt Academie in 1986 (see MENSCH, Peter van. Museality at breakfast. The concept of museality in contemporary museological discourse. Museologica Brunensia, 2015, vol. 4, no. 2, pp. 14-19.).
François Mairesse has shown that Stránský's work on musealisation can still be of value in a further development of the concept. ${ }^{60}$ Stránský himself reflected on the work of Lübbe, Baudrillard, Jeudy, and others, which also shows that there is a potential for further development. ${ }^{61}$ The challenge is to make a connection with the New Museology, Museum Studies and Critical Heritage Studies discourses. Whereas the term has become a familiar component of the professional rhetoric in Germany (and many other countries), native speakers in Great Britain seem to feel uncomfortable with it. Anyway, the new interest in documenting the present ${ }^{62}$ and the introduction of new concepts, such as "musealisation lite" ${ }^{63}$ and "third space" ${ }^{4}$ could help to find new directions in the discussion.

In an earlier issue of Museologica Brunensia, I have developed some thoughts about the concept of museality and its future. ${ }^{65}$ At the end I was a bit ambivalent about the use of the term. I still think it would be worthwhile to make an in-depth comparison of the concepts of her-

60 MAIRESSE, François. Muséalisation. In DESVALLÉES, André and François MAIRESSE. Dictionnaire encyclopédique de muséologie. Paris: Armand Collin, 2011, pp. 251-269.

61 STRÁNSKÝ, Z. Z. Musealisierung und Paradigmenwechsel. Museum aktuell, Mai/Juni 2001, pp. 2802-2806; STRÁNSKÝ, Zbyněk Z. Muzealizace z hlediska noetiky a ontologie. In Muzealizace $v$ soudobé společnosti a poslání muzeologie/ Musealization in contemporary society and role of museology. Anthology from symposium with foreign participation on the occasion of anniversary of the founder of the Brno museology school Zbyněk Z. Stránský. Technical Museum in Brno, $8^{\text {th }}-10^{\text {th }}$ November 2006. Prague: Asociace muzeí a galerií České republiky, 2008, pp. 78-85

62 ELPERS, Sophie and Anna PALM (eds.). Die Musealisierung der Gegenwart. Von Grenzen und Chancen des Sammelns in kulturhistorischen Museen. Bielefeld: Transcript Verlag, 2014.

63 MENSCH, Peter van and Léontine MEIJER-VAN MENSCH. New Trends in Museology II. Celje: Muzej novejše zgodovine, 2015, pp. 19-20.

64 MENSCH, Peter van. Museality at breakfast. The concept of museality in contemporary museological discourse. Museologica Brunensia, 2015, vol. 4, no. 2, pp. 14-19.

65 MENSCH, Peter van. Museality at breakfast. The concept of museality in contemporary museological discourse. Museologica Brunensia, 2015 , vol. 4, no. 2, pp. 14-19. itage as, for example, advocated by Laurajane Smith ${ }^{66}$ and Stránský's developing concept of museality.

Müller-Straten may (partly) de right in his observation that a generation of museologists is gradually disappearing leaving "not enough prolific teachers in scientific Museology". ${ }^{67}$ The observations of Walz underline the problem. ${ }^{68}$ Nevertheless, I think there is again a growing number of young academics and museum workers that are interested in museums and musealisation, but they do perhaps not define themselves as museologists. For me, this is not important. In hindsight it might be a pity that Stránský spend much of his energy to prove that museology is a science. This is not the main issue today. What still remains relevant in contemporary society is a reflection on the specificity of the relation of people with their environment as expressed in the concept of heritage.

\section{REFERENCES:}

AUER, Hermann (ed.). Museologie. Neue Wege - Neue Ziele. Bericht über ein internationales Symposium, veranstaltet von den ICOM-Nationalkomitees der Bundesrepublik Deutschland, Österreichs und der Schweiz vom 11. bis 14. Mai 1988 am Bodensee. München: K. G. Sauer, 1989. ISBN 978-3-598-10809-9.

BEIER, Hans-Jürgen and Volker SCHIMP-

FF. Editorial. Curiositas. Jahrbuch für Museologie und museale Quellenkunde, 2014-2015, no. 14-15, pp. 1-2.

66 SMITH, Laurajane. Uses of heritage. Abbingdon: Routledge, 2006.

67 MÜLLER-STRATEN, Christian. The contribution of Zbyněk Stránský to Museology and the contribution of the Brno Museology School. In Muzealizace $v$ soudobé společnosti a poslání muzeologie/Musealization in contemporary society and role of museology. Anthology from symposium with foreign participation on the occasion of anniversary of the founder of the Brno museology school Zbyněk Z. Stránský. Technical Museum in Brno, $8^{\text {th }}-10^{\text {th }}$ November 2006. Prague: Asociace muzeí a galerií České republiky, 2008, p. 33.

68 WALZ, Markus. On the current ascendancy of special museology in Germany. Museologica Brunensia, 2015, vol. 4, no. 2, pp. 20-27. 
BIEDERMANN, Bernadette. Theoretische Modelle und aktuelles museales Ausstellungswesen im Spiegel des Theorems der Musealität. Museologica Brunensia, 2015, vol. 4, no. 2, pp. 33-41. ISSN 1805-4722.

BIEDERMANN, Bernadette and Marlies RAFFLER. Dem Museologen, Volkskundler, Jazzmusiker, Komponisten, Arrangeur, Pädagogen, Museumskonsulenten, Mentor, Philosophen, Polyhistor, Menschen und Freund Friedrich Waidacher zum 80. Geburtstag. Curiositas. Jahrbuch für Museologie und museale Quellenkunde, 2014-2015, no. 14-15, pp. 3-14.

BIEDERMANN, Bernadette, Marlies RAFFLER and Nikolaus REISINGER. Geleitwort. Curiositas. Jahrbuch für Museologie und museale Quellenkunde, 2012-2013, no. 12-13, pp.1-2.

Chamada para textos e comunicações para o III Ciclo de Debates Internacional Stránský: uma ponte Brno-Brazil [online]. [cit. 2016-09-27]. Available from www: <http://www.forumpermanente.org/ noticias/2015/chamada-para-textos-e-comunicacoes-para-o-iii-ciclo-de-debates-internacional-stransky-uma-ponte-brno-brazil >.

COLLENBERG-PLOTNIKOV, Bernadette. Die Musealisierung des Alltäglichen. Zur Bedeutung der Institutionen für die Kunst. In WIESING, Lambert (ed.). Ästhetik und Alltagserfahrung. VII. Kongress der Deutschen Gesellschaft für Ästhetik. [Jena], 2008. Kongress-Akten der Deutschen Gesellschaft für Ästhetik 1.

COLLENBERG-PLOTNIKOV, Bernadette. Kunst zeigen - Kunst machen. Überlegungen zur Bedeutung des Museums. In COLLENBERG-PLOTNIKOV, Bernadette (ed.). Musealisierung und Reflexion. Gedächtnis - Erinnerung - Geschichte. München: Wilhelm Fink Verlag, 2011. ISBN 978-3-7705-4770-8.

DESVALLÉES, André and François MAIRESSE. Dictionnaire encyclopédique de muséologie. Paris: Armand Collin, 2011. ISBN 978-2-200-27037-7.

DOLÁK, Jan and Jana VAVŘíKOVÁ. Muze$\operatorname{olog} Z$ Z. Z. Stránský. Život a dílo. Brno: Masarykova univerzita, 2006. ISBN 80210-4139-0.

DYROFF, Hans-Dieter (ed.). Museologie. Bericht über ein internationales Symposi- um, veranstaltet vom Deutschen Nationalkomitee des Internationalen Museumsrates (ICOM) in Zusammenarbeit mit der Deutschen UNESCO-Kommission vom 8. bis 13. März 1971 in München. Köln: Deutsche UNESCO-Kommission, 1973. ELPERS, Sophie and Anna PALM (eds.). Die Musealisierung der Gegenwart. Von Grenzen und Chancen des Sammelns in kulturhistorischen Museen. Bielefeld: Transcript Verlag, 2014. ISBN 978-3-8394-2494-0.

FLÜGEL, Katharina. Einführung in die $M u-$ seologie. Darmstadt: Wissenschaftliche Buchgesellschaft, 2005. ISBN 978-3-534-73884-7.

FLÜGEL, Katharina and Arnold VOGT (eds.) Museologie als Wissenschaft und Beruf in der modernen Welt. Leipziger Gespräche zur Museologie. Leipzig: Hochschule für Technik, Wirtschaft und Kultur, 1995. Schriftenreihe zur Museologie 3. ISBN 978-3-929742-56-5.

GUBARENKO, Maria. Czech-Russian (Czechoslovak-Soviet) cooperation in the field of formation and development of museology as a science. Museologica Brunensia, 2016, vol. 5, no. 1, pp. 15-25. ISSN 1805 4722. DOI: 10.5817/MuB2016-1-2

HANSLOK, Andreas. Museologie und Archivwissenschaft in der DDR. Abgrenzung und Annäherung zweier Nachbarwissenschaften. Marburg: Tectum Verlag, 2008. ISBN 978-3-8288-9581-2.

HEESEN, Anke te. Theorien des Museums zur Einführung. Hamburg: Junius Verlag, 2012. ISBN 978-3-88506-698-9.

HERBST, Wolfgang and Konstantin G. LEVYKIN (eds.). Museologie. Theoretische Grundlagen und Methodik der Arbeit in Geschichtsmuseen. Berlin: VEB Deutscher Verlag der Wissenschaften, 1988.

KIRSCH, Otakar. Vysokoškolská výuka muzeologie v Brně v době normalizace a nástupu demokratického režimu. $M u$ seologica Brunensia, 2014, vol. 3, no. 5, pp. 12-20. ISSN 1805-4722.

KLAUSEWITZ, Wolfgang. Zur Geschichte der Museologie (1878-1988). In AUER, Hermann (ed.). Museologie. Neue Wege - Neue Ziele. Bericht über ein internationales Symposium, veranstaltet von den ICOM-Nationalkomitees der Bundesrepublik Deutschland, Österreichs und der Schweiz vom 11. bis 14. Mai 1988 am Bodensee.
München: K. G. Sauer, 1989, pp. 20-37. ISBN 978-3-598-10809-9.

LANG, Rolf (ed.). Museologie in der Tschechoslowakischen Sozialistischen Republik. Berlin, 1982. Schriftenreihe des Instituts für Museumswesen 17.

LÜBBE, Hermann. Der Fortschritt und das Museum. Über den Grund unseres Vergnügens an historischen Gegenständen. The 1981 Bithell Memorial Lecture. London: Institute of Germanic Studies, 1982.

LUDWIG, Andreas and Markus WALZ. Museen als Forschungsgegenstand anderer Wissenschaften. In WALZ, Markus. Handbuch Museum. Geschichte-AufgabenPerspektiven. Stuttgart: J. B. Metzler, 2016, pp. 375-381. ISBN 978-3-476-02375-9.

MACDONALD, Sharon and Helen Rees LEAHY (eds.). International Handbooks of Museum Studies. Chichester: WileyBlackwell, 2015. ISBN 978-1-4051-9850-9.

MAIRESSE, François. Muséalisation. In DESVALLÉES, André and François MAIRESSE. Dictionnaire encyclopédique de muséologie. Paris: Armand Collin, 2011, pp. 251-269. ISBN 978-2-200-27037-7.

MAIRESSE, François. Museology at a crossroads. Museologica Brunensia, 2015, vol. 4, no. 2, pp. 4-9. ISSN 1805-4722.

MAROEVIĆ, Ivo. Introduction to Museology the European Approach. München: Verlag Dr. Christian Müller-Straten, 1998. ISBN 3-932704-52-5.

MAROEVIĆ, Ivo. Zur Kritik der museologischen Theorien Zbynek Z. Stránskýs. $M u$ seum aktuell, 2001, Juli, pp. 2887-2892.

MARSTINE, Janet. Introduction. In MARSTINE, Janet (ed.). New museum theory and practice. Oxford: Blackwell, 2008, pp. 1-36. ISBN 978-1-4051-4882-5.

MENSCH, Peter van. Museality at breakfast. The concept of museality in contemporary museological discourse. Museologica Brunensia, 2015, vol. 4, no. 2, pp. 14-19. ISSN 1805-4722.

MENSCH, Peter van. Museologie - Wissenschaft für Museen. In WALZ, Markus. Handbuch Museum. Geschichte - Aufgaben - Perspektiven. Stuttgart: J. B. Metzler, 2016, pp. 370-375. ISBN 978-3-476-02375-9.

MENSCH, Peter van. Needles in a haystack Some reflections from the Working Group 
on Resources. COMCOL Newsletter, 2015, vol. 29, pp. 19-21.

MENSCH, Peter van. Towards a methodology of museology. Zagreb: University of Zagreb, 1992. PhD thesis.

MENSCH, Peter van and Léontine MEIJER-VAN MENSCH. New Trends in Museology II. Celje: Muzej novejše zgodovine, 2015. ISBN 978-961-6339-39-1.

MESSAGE, Kylie and Andrea WITCOMB. Introduction: museum theory. An expanded field. In WITCOMB, Andrea and Kylie MESSAGE (eds.). Museum Theory. The International Handbooks of Museum Studies 1. Chichester: Wiley-Blackwell, 2015, pp. xxxv-lxiii. ISBN 978-1-4051-9850-9.

MÜLLER-STRATEN, Christian. The contribution of Zbyněk Stránský to Museology and the contribution of the Brno Museology School. In Muzealizace v soudobé společnosti a poslání muzeologie/Musealization in contemporary society and role of museology. Anthology from symposium with foreign participation on the occasion of anniversary of the founder of the Brno museology school Zbyněk Z. Stránský. Technical Museum in Brno, $8^{\text {th }}-10^{\text {th }} \mathrm{No}$ vember 2006. Prague: Asociace muzeí a galerií České republiky, 2008, pp. 2735. ISBN 978-80-86611-28-0.

MÜLLER-STRATEN, Christian. Wie in der DDR Museologie gemacht wurde: Die kommunistische Abrechnung mit Z. Z. Stránský. Museum aktuell, 2005, Juli/ August, pp. 40-41.

Museologie. In Wikipedia. Die freie Enzyklopädie [online]. [cit. 2016-09-27]. Available from www: <https://de.wikipedia.org/wiki/Museologie $>$.

RAFFLER, Marlies. Spiegel der Nation? Zugänge zur Historischen Museologie am Beispiel der Genese von Landes- und Nationalmuseen in der Habsburgermonarchie. Wien: Böhlau Verlag, 2007. ISBN 978-3-205-77731-1.

RUTAR, Václav. Vznik, vývoj a práce externí katedry muzeologie v Brnĕ v letech 1963-1969. Museologica Brunensia, 2014, vol. 3, no. 5, pp. 4-11. ISSN 1805-4722.

SCHEUNEMANN, Jan. „Gegenwartsbezogenheit und Parteinahme für den Sozialismus“. Geschichtspolitik und regionale Museumsarbeit in der SBZ/DDR 1945-1971. Berlin: Metropol Verlag, 2009. ISBN 978-3-940938-35-0.
SCHREINER, Klaus. Einführung in die Museologie - ein Beitrag zu den theoretischen Grundlagen der Museumsarbeit. Neubrandenburg, 1982.

SMITH, Laurajane. Uses of heritage. Abbingdon: Routledge, 2006. ISBN 978-0-415-31830-3.

STRÁNSKÝ, Zbyněk. Die Museologie als selbständige Wissenschaft. In FLÜGEL, Katharina and Arnold VOGT (eds.). $\mathrm{Mu}$ seologie als Wissenschaft und Beruf in der modernen Welt. Leipziger Gespräche zur Museologie. Leipzig: Hochschule für Technik, Wirtschaft und Kultur Leipzig, 1995, pp. 11-29. Schriftenreihe zur Museologie 3. ISBN 978-3-929742-56-5.

STRÁNSKÝ, Zbyněk. Die theoretischen Grundlagen der Museologie als Wissenschaft. In AUER, Hermann (ed.). Museologie. Neue Wege - Neue Ziele. Bericht über ein internationales Symposium, veranstalt et von den ICOM-Nationalkomitees der Bundesrepublik Deutschland, Österreichs und der Schweiz von 11. bis 14. Mai 1988 am Bodensee. München: K. G. Sauer, 1989, pp. 38-47. ISBN 978-3-598-10809$-9$.

STRÁNSKÝ, Zbyněk Z. Ist Museologie eine kommunistische Wissenschaft? Eine Entgegnung auf deutsche Einstellungen. $\mathrm{Mu}$ seum aktuell, April 2001, pp. 2758-2761.

STRÁNSKÝ, Z. Z. Musealisierung und Paradigmenwechsel. Museum aktuell, Mai/ Juni 2001, pp. 2802-2806

STRÁNSKÝ, Zbyněk Z. Muzealizace z hlediska noetiky a ontologie. In Muzealizace $v$ soudobé společnosti a poslání muzeologie/Musealization in contemporary society and role of museology. Anthology from symposium with foreign participation on the occasion of anniversary of the founder of the Brno museology school Zbyněk Z. Stránský. Technical Museum in Brno, 8th-10th November 2006. Prague: Asociace muzeí a galerií České republiky, 2008, pp. 78-85. ISBN 978-80-86611-28-0.

STRÁNSKÝ, Zbyněk Z. [Museology - science or just practical museum work]. Museological Working Papers, 1980, no. 1, pp. 42-44.

STRÁNSKÝ, Z. Z. Museology as a science (A Thesis). Museologia, 1980, vol. 15, pp. 33-40.
STRÁNSKÝ, Zbyněk Z. Noch eine „knapp gefasste Museologie“. Museum aktuell, November 2008, pp. 6-7.

STRÁNSKÝ, Z. Z. (ed.). Sborník materiálů prvého muzeologického sympozia. Brno: Moravské muzeum, 1966.

STURM, Eva. Konservierte Welt. Museum und Musealisierung. Berlin: Dietrich Reimer Verlag, 1991. ISBN 978-3-496-01078-4.

WAIDACHER, Friedrich. Handbuch der Allgemeinen Museologie. Wien: Böhlau Verlag, 1993. ISBN 978-3-205-98445-0.

WALZ, Markus. Handbuch Museum. Geschichte - Aufgaben - Perspektiven. Stuttgart: J. B. Metzler, 2016. ISBN 978-3-476-02375-9.

WALZ, Markus. On the current ascendancy of special museology in Germany. $\mathrm{Mu}$ seologica Brunensia, 2015, vol. 4, no. 2, pp. 20-27. ISSN 1805-4722.

\section{PETER VAN MENSCH}

freelance museologist, Berlin (Germany) and Loučná-Višňová (Czech Republic) peter@menschmuseology.com

Peter van Mensch is currently freelance museologist, and formerly professor of cultural heritage at the Reinwardt Academie (Amster dam) and professor of museology at Vilnius University (Lithuania). Being a Dutch citizen, he lives partly in Berlin and partly in Loučná-Višňová (Czech Republic), reflecting his lifetime ambition to make a connection between the Central European tradition(s) concerning the theory of museology with contemporary museological thinking elsewhere.

Peter van Mensch je v současnosti muzeologem na volné noze. Dříve působil jako profesor kulturního dědictví na Reinwardt Academie (Amsterdam) a profesor muzeologie na Univerzitě ve Vilniusu (Litva). Je občanem Nizozemska, žije částečně v Berlíně a částečně v Loučné-Višňové (Česká republika). Odráží to jeho celoživotní snahu o propojení středoevropské tradice $\mathrm{v}$ teorii muzeologie se současným muzeologickým myšlením jinde ve světě. 